$14^{\text {th }}$ Conf. Agric. Develop. Res., Fac. of Agric., Ain Shams

Univ., March, 2019, Cairo, Egypt

Special Issue, 27(1), 375 - 382, 2019

Website: http://strategy-plan.asu.edu.eg/AUJASCI/

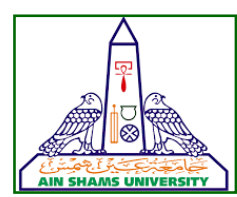

375

\title{
IN VITRO EVALUATION OF ENCAPSULATED PROBIOTIC BACTERIA SUPPLEMENTATION TO RUMINANT RATIONS
}

$[35]$

\author{
Makled $^{1 \star}$, A.M., Khorshed ${ }^{1}$, M.M., Gouda ${ }^{1}$, G.F., El-Garhi ${ }^{2}$, M.S., Ebeid ${ }^{3}$, H.M., \\ Azzaz $^{3}$, H.H., Abdelgawad ${ }^{3}$, R.M.A., Mona. S. Zayed ${ }^{4}$, Hoda S. El-Sayed ${ }^{3}$ \\ and El-Bordeny ${ }^{1}$ N.E. \\ 1. Animal Production Dept., Fac. of Agric., Ain Shams Univ., P.O. Box 68 Hadayek Shoubra, 11241, Cairo, \\ Egypt. \\ 2. Animal Reproduction Research Institute, Agricultural Research Center, Giza, Egypt. \\ 3. Dairy Sciences Dept., National Research Centre, Dokki, Giza, 12311, Egypt \\ 4. Agric. Microbiology Dept., Fac. of Agric., Ain Shams Univ., P.O. Box 68 Hadayek Shoubra, 11241, \\ Cairo, Egypt.
}

\section{${ }^{*}$ Corresponding author: ahmed.makled59@gamil.com}

Received 8 December, 2018, $\quad$ Accepted 8 January, 2019

\begin{abstract}
The aim of this study was to in-vitro evaluate encapsulated probiotic supplementation to ruminant rationson degradation and fermentation parameters. The ration consisted of $40 \%$ alfalfa hay and $60 \%$ concentrate feed mixture. Encapsulated and not encapsulated probiotic were supplemented with level of $10^{6} \mathrm{cfu} / \mathrm{kg}$ of the total dry matter of ration (DM) and compared with encapsulation media (Sodium Alginate, SA) and control (not supplemented ration). DM and $\mathrm{OM}$ degradation and total gas production as well as fermentation parameters of the incubated samples were determined after $24 \mathrm{~h}$ of fermentation. Significant $(\mathrm{P}<0.01)$ increases in in-vitro DM degradability was observed for the experimental ration supplemented with encapsulated or not encapsulated probiotics at levels $\left(10^{6} \mathrm{CFU} / \mathrm{kg} \mathrm{DM}\right)$ and SA treatment compared to control ration. Also, significant $(P<0.05)$ improvement in $\mathrm{OM}$ degradability was recorded for the ration supplemented with not encapsulated probiotics bacteria compared to the other treatments. Moreover no significant differences were observed between the control ration and the rations supplemented with encapsulated probiotics or SA only, as well as no significant difference was recorded between the ration supplemented with encapsulated probiotics and the ration supplemented with SA only. Probiotics bacteria supple-
\end{abstract}

mentation in the form of not encapsulated probiotic resulted significant increases in in vitro total gas production per sample and per $\mathrm{g} \mathrm{DM}, \mathrm{OM}, \mathrm{dDM}$, NDF and ADF after 24 hours incubation period compared to the other experimental rations (control, encapsulated probiotic and SA). While significant increase in total gas production per $\mathrm{g} d O M$ was observed for not encapsulated probiotic compared to encapsulated probiotic only. It could be concluded that, using encapsulated probiotics bacteria had no significant effect on DM degradability and may be induce decrease in gas production and fermentation parameters.

Key words: Probiotics, Encapsulation, in-vitro, fermentation, Degradation.

\section{INTRODUCTION}

Improvements of animal productivity, feed utilization and animal health are the aims of rumen microbial studies. These aims could be achieved by producing desirable fermentation products as probiotics or direct fed microbial (DFM). Many of the feed additives have been used to improve animal productivity and feed utilization efficiency. The probiotics (direct-fed microbial, DFM) are microbial growth promoters that could be manipulating the rumen fermentation characteristics in intestinal tracts of livestock animals (Weiss et al 2008). 


\section{Makled, Khorshed, Gouda, El-Garhi, Ebeid, Azzaz, Abdelgawad, Mona Zayed, Hoda El-Sayed and El-Bordeny}

The name probiotic comes from the Greek 'pro bios' which means 'for life'. The term "probiotic" has been defined as "a live microbial feed supplement, which affects beneficially of the host animal through improving the microbial balance in the intestine" (Fuller, 1989). Also, they are known as direct-fed microbial (DFM). Probiotic or DFM have been used to describe viable microorganisms, enzymes, culture extracts, exopolysaccharides or any combinations of them (Yoon and Stern, 1995).

The use of probiotic additives has been developed as alternatives to antibiotics to improve animal health and productivity (Allen et al 2013), Probiotic supplements were also shown to increase carcass output and water holding capacity, and decrease cooking loss and meat hardness (Ceslovas et al 2005). Lactobacillus bacillus as a probiotic has several potential benefits like growth promotion of farm animals (Tripathi and Karim, 2009), protection against pathogens(Casas and Dobrogosz, 2000), alleviation of lactose intolerance (Mustapha and Savaiano, 1996), relief of constipation, anti-cholesterolemic effect, reduction of gut $\mathrm{pH}$ by stimulating the lactic acid producing micro-flora, competition with pathogens for a viable nutrients (Edens,2003) and immune-modulation (Aottouri et al 2002).

The encapsulation process for probiotics may be increase the number of the probiotic escape to the intestine, consequently acts it role in the intestine and increase animal immunity. So, the objectives of this study were to evaluate effect of encapsulation probiotic supplementation to ruminant ration on in vitro degradation and fermentation parameters.

\section{MATERIALS AND METHODS}

\section{Microbial strains and growth condition}

Lactobacilli isolates were grown on MRS broth (Oxoid) and Streptococci isolates were grown on M17 broth (Difco), after that the broth media incubated for $24 \mathrm{~h}$ at $37^{\circ} \mathrm{C}$. The strains were activated two or three times in order to obtain high biomasses in the stationary phase then the cell pellets were harvested by centrifugation at 5000rpm, for $20 \mathrm{~min}$ at $4^{\circ} \mathrm{C}$. The pellets were washed by sterile saline solution $(0.9 \%(\mathrm{w} / \mathrm{v}) \mathrm{NaCl})$ and recovered under the same centrifugation conditions then stored at $-8^{\circ} \mathrm{C}$ till be encapsulated.
Preparation of Encapsulated mixed strains using extrusion method

Generally, the microencapsulation process was performed using the extrusion technique (ELShafei et al 2018). One part of the cells of different isolates suspension was mixed with three parts of the freshly prepared sodium alginate $(3 \%)$ with gentle stirring for 10-20 min. The mixture was then extruded into the hardening solution $\left(\mathrm{CaCl}_{2}, 0.2 \mathrm{M}\right)$ through sterile syringe ( $25 \mathrm{G}, 0.5 \mathrm{~mm}$ ) with gentle stirring for $30 \mathrm{~min}$ to ensure complete solidification. The formed microcapsules were harvested by filtration then washed by sterile saline solution.

\section{Enumeration of the microencapsulated cells}

The viability of mixed strains was assessed as described by (Chávarri et al 2010). One gram of the microcapsules was dissolved in $9 \mathrm{ml}$ of sterile tri-sodium citrate solution $(2 \% \mathrm{w} / \mathrm{v})$ and vortexes till complete dissolution then the samples were serially diluted to appreciate concentration using saline solution and pour plated in MRS agar for lactobacilli and in M17 agar for streptococii. The plates were incubated $48 \mathrm{~h}$ at $37^{\circ} \mathrm{C}$. The viable cell number was expressed as colony forming unit per gram of microcapsule (cfu/g).

\section{Experimental ration and treatments}

The tested ration contained 60:40 concentrate: roughage ratio, the concentrate portion was composed of corn, soyabean, wheat bran, flaxseed, $\mathrm{CaCO}_{3}$, salt and mineral mixture while the roughage portion was alfalfa hay. The data of chemical composition of the feed ingredients and tested rations are presented in Table (1). Encapsulated and not encapsulated probiotic supplementation with level of $10^{6} \mathrm{cfu} / \mathrm{kg}$ of the total ration DMwerecompared with encapsulation media (Sodium Alginate, SA) and control (not supplemented).

\section{In vitro gas production technique}

Two days before beginning of the experiment, $400 \pm 4 \mathrm{mg}$ ( $240 \mathrm{mg}$ CFM $+160 \mathrm{mg}$ alfalfa hay) of sample for each treatment was weighed into 125 $\mathrm{mL}$ glass bottles. These bottles have a total volume of $125 \pm 2 \mathrm{~mL}$. A buffer solution was prepared before addition of rumen fluid as described by McDougall (1948) and flushed continuously with $\mathrm{CO}_{2}$ at $39^{\circ} \mathrm{C}$ during sample inoculation. 
Rumen fluid was obtained from slaughter house and it was collected from beef steers. The collected rumen fluid was mixed into a bottle (1L) with an $\mathrm{O}_{2}$-free headspace and immediately transported to laboratory at $39^{\circ} \mathrm{C}$. Upon arrival at the laboratory, the rumen fluid was filtered through four layers of cheesecloth to eliminate large feed particles. The buffer solution was added to rumen fluid at ratio $4: 1$. Forty $\mathrm{mL}$ of thisinoculums was added to each bottle, then the headspace of each bottle was flushed with $\mathrm{CO}_{2}$, and closed. The initial $\mathrm{pH}$ of the inoculums was from 6.8-6.9. Triplicates of each sample were used for each treatment.

Table 1. The chemical composition of the concentrate feed mixture and alfalfa hay

\begin{tabular}{|lcc|}
\hline \multicolumn{1}{|c}{ Item } & $\begin{array}{c}\text { Alfalfa } \\
\text { hay }\end{array}$ & $\begin{array}{c}\text { Concen- } \\
\text { trate feed } \\
\text { mixture }\end{array}$ \\
\hline Dry matter & 889.5 & 890.9 \\
Organic matter & 878.7 & 933.7 \\
Neutral detergent fiber & 460.6 & 184.3 \\
Acid detergent fiber & 359.7 & 59.4 \\
Acid detergent lignin & 41.6 & 10.4 \\
Crude protein & 208.5 & 157.3 \\
Ether extract & 28.4 & 47.4 \\
Ash & 121.3 & 66.3 \\
Non-fiber carbohydrate & 181.2 & 544.7 \\
\hline
\end{tabular}

\section{Degradability}

Dry matter degradability (\% dDM) was calculated as the (difference between the sample DM content and that in the residual after $48 \mathrm{~h}$ incubation / sample DM content * 100).

\section{Total gas production}

After $24 \mathrm{~h}$ of samples incubation, the total gas production was estimated by the displacement of syringe piston, which was connected to the serum flasks. The gas produced due to fermentation of substrate was calculated by subtracting gas produced in blank vessels (without substrate) from total gas produced in the vessels containing buffered rumen fluid and substrate.

\section{Calculation}

In vitro organic matter digestibility (OMD, g/kg $\mathrm{OM}$ ) were estimated according to (Menke and Steingass, 1988) as:

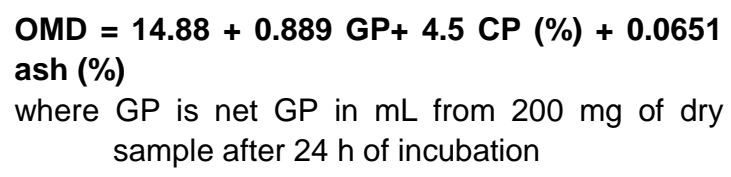

After 24 hrs of incubation, the filtrated rumen liquor for each sample was subjected for further investigation. The $\mathrm{pH}$ of rumen fluid was measured using $\mathrm{pH}$ meter pen, Quantitative analysis of ammonia concentration was carried out by Nesler method modified by Szumacher-Strabel et al (2002) and total volatile fatty acids(TVFA's) was determined according to(Barnett and Reid, 1957).

\section{Gas production calculation}

After 24 hours gas production was calculated as followed

GP per g DM = total gas production ( $\mathrm{ml}$ ) / substrate DM $(g)$

GP per $\mathrm{g} O M=$ total gas production ( $\mathrm{ml}$ ) / substrate $\mathrm{OM}(\mathrm{g})$

GP per $\mathrm{g} \mathrm{NDF}=$ total gas production $(\mathrm{ml}) /$ substrate NDF $(\mathrm{g})$

GP per $g$ ADF = total gas production $(\mathrm{ml}) /$ substrate ADF (g)

\section{Chemical analysis of feed ingredients}

Concentrate feed mixture and alfalfa hay were analyzed for DM, ash, (CF) crude fiber; crude protein (CP) (Nitrogen $x$ 6.25) and ether extract (EE) contents according to AOAC (1997). Neutral detergent fiber (NDF), acid detergent fiber (ADF) and (ADL) acid detergent lignin contents were analyzed sequentially (Van Soest et al 1991) using the Ankom ${ }^{200}$ Fibre Analyzer for NDF and ADF. The NDF content was analyzed with 2 additions of heat-stable $\alpha$-amylase and $1: 1 \mathrm{~g}$ sodium sulfite per $g$ sample in the neutral detergent solution. NDF and ADF are expressed inclusive of residual ash. Non-fiber carbohydrate (NFC) was calculated according to the following formula:

NFC $(\%)=100-(\% N D+\% C P+\%$ fat $+\%$ ash) (NRC, 2001).

\section{Statistical analysis}

The data of In vitro degradability and fermentation parameters were statistically analyzed according to statistical analysis system User's Guide, (S.A.S., 1998). Separation among means was carried out by using Duncan Multiple test, (Duncan, 1955). The following model was used: 
Where:

$$
Y_{i j}=\mu+T_{i}+e_{i j}
$$

$\mathrm{Y} \mathrm{ij}=$ the observation of the model, $\mu=$ General mean common element to all observation, $\mathrm{Ti}$ $=$ the effect of the treatment $\mathrm{i}$, and $\mathrm{e} \mathrm{ij}=$ the effect of error

\section{RESULTS AND DISCUSSION}

\section{Dry matter and organic matter degradation}

The data of Table (2) showed effect of not encapsulated, encapsulated probiotics and SA supplementation to the tested ration compared to the control on in vitro dry matter and organic matter degradability. The data showed significant $(P<0.05)$ increase in in-vitro DM degradability was observed for the experimental ration supplemented with encapsulated or not encapsulated probiotics at levels $\left(10^{6} \mathrm{cfu} / \mathrm{kg} \mathrm{DM}\right)$ and SA compared to control ration (not supplemented).While no significant differences were observed among the supplemented ration with probiotics bacteria encapsulated or not encapsulated at levels $\left(10^{6} \mathrm{cfu} / \mathrm{kg} \mathrm{DM}\right)$ and Sodium Alginate treatments. These may be due to the probiotic supplementation which stimulate rumen bacteria growth (Chiquette et al 2008) and fermentation (Stein et al 2006), consequently improve DM degradation. Also, may be due to effect of encapsulated medium(Sodium Alginate) for the treatments supplemented with encapsulated probiotic and SA only.

Table 2. Effect of encapsulated and not encapsulated probiotics supplementation on in vitro DM and OM degradability after 24 hours incubation period.

\begin{tabular}{|c|c|c|c|c|c|c|}
\hline $\begin{array}{c}\text { Degrada- } \\
\text { tion }\end{array}$ & Control & $\begin{array}{c}\text { Probi- } \\
\text { otic }\end{array}$ & $\begin{array}{c}\text { Algi- } \\
\text { nate }\end{array}$ & $\begin{array}{c}\text { Encap- } \\
\text { sulated } \\
\text { probi- } \\
\text { otic }\end{array}$ & SE & P value \\
\hline $\begin{array}{c}\text { Dry mat- } \\
\text { ter,\% } \\
\text { Organic } \\
\text { matter, } \%\end{array}$ & $43.21^{\mathrm{b}}$ & $46.45^{\mathrm{a}}$ & $48.108^{\mathrm{a}}$ & $50.08^{\mathrm{a}}$ & 0.96 & 0.0005 \\
\hline
\end{tabular}

${ }^{a}$ and ${ }^{b}$ Different superscript are significantly different $(P<0.05)$
Concerning to effect of experimental treatments on OM degradability (\%), the data indicated that significant $(\mathrm{P}<0.05)$ improvement in $\mathrm{OM}$ degradability was recorded for the ration supplemented with not encapsulated probiotics bacteria compared to the other treatments. Moreover no significant differences were observed between the control ration and the rations supplemented with encapsulated probiotics or encapsulation medium only (Sodium Alginate), as well as no significant difference was recorded between the ration supplemented with encapsulated probiotics and the ration supplemented with encapsulated material only. This may be due to the stimulation effect of probiotics for rumen flora and fermentation (Stein et al 2006). Which, the encapsulation process protect the probiotic bacteria and prevent its effect on rumen flora.

\section{Gas Production}

Gas production is a good indicator of microbial ferment ability, digestibility and rumen protein production (Salem et al 2014). Effect of encapsulated and not encapsulated probiotics supplementation on In-vitro total gas production per g DM, OM, dDM, dOM, NDF and ADF after 24 hours incubation period are presented in Table (3). Probiotic bacteria supplementation in the not encapsulated form resulted significant increases in in vitro total gas production per g DM, OM, dDM, NDF and ADF after 24 hours incubation period compared to the other experimental rations (control, encapsulated probiotic and SA medium). While significant increase in total gas production per g dOM was observed for not encapsulated probiotic compared to encapsulated probiotic only. This may be due to effect of DM and OM degradation improvement for the not encapsulated probiotic treatment compared to the other experimental treatments (Table 2).

These results are agree with Sheikh et al (2017) who found increase in total gas production when add probiotic mix contains Saccharomyces and Lactobacillus acidophilus to the ration compared to control. Also Ganaiet al. (2015)recorded higher in vitro total gas productionwhensupplementedbajra straw baseddietwith yeast. In this connection Blümmel and Ørskov(1993) reported that fermentation of organic compounds produces gas as one of the end-products providing the foundation of the strong correlation between OM digestibility and volume of gas produced. 
Table 3. Effect of encapsulated and not encapsulated probiotics supplementation on in-vitro total gas production per g DM, OM, dDM, dOM, NDF and ADF after 24 hours incubation period.

\begin{tabular}{|c|c|c|c|c|c|c|}
\hline Item & Control & Probiotic & Alginate & $\begin{array}{c}\text { Encapsulated } \\
\text { probiotic }\end{array}$ & SE & P value \\
\hline GP/g DM, ml & $104.70^{\mathrm{b}}$ & $115.3^{\mathrm{a}}$ & $104.90^{\mathrm{b}}$ & $101.94^{\mathrm{b}}$ & 1.772 & 0.0001 \\
$\mathrm{GP} / \mathrm{g} \mathrm{dDM}, \mathrm{ml}$ & $87.94^{\mathrm{a}}$ & $90.16^{\mathrm{a}}$ & $79.23^{\mathrm{b}}$ & $73.70^{\mathrm{c}}$ & 1.75 & 0.0001 \\
$\mathrm{GP} / \mathrm{g} \mathrm{OM}, \mathrm{ml}$ & $115.00^{\mathrm{a}}$ & $126.60^{\mathrm{a}}$ & $115.23^{\mathrm{b}}$ & $111.98^{\mathrm{b}}$ & 1.95 & 0.0001 \\
$\mathrm{GP} / \mathrm{g} \mathrm{dOM}, \mathrm{ml}$ & $111.50^{\mathrm{ab}}$ & $114.40^{\mathrm{a}}$ & $110.55^{\mathrm{ab}}$ & $108.08^{\mathrm{b}}$ & 1.53 & 0.0517 \\
$\mathrm{GP} / \mathrm{g} \mathrm{NDF}, \mathrm{ml}$ & $322.60^{\mathrm{b}}$ & $355.20^{\mathrm{a}}$ & $323.08^{\mathrm{b}}$ & $313.97^{\mathrm{b}}$ & 5.527 & 0.0001 \\
$\mathrm{GP} / \mathrm{g} \mathrm{ADF}, \mathrm{ml}$ & $530.10^{\mathrm{b}}$ & $583.50^{\mathrm{a}}$ & $530.71^{\mathrm{b}}$ & $515.75^{\mathrm{b}}$ & 9.18 & 0.0001 \\
\hline
\end{tabular}

${ }^{a}$ and ${ }^{b}$ Different superscript are significantly different $(\mathrm{P}<0.05)$

\section{Fermentation parameters}

Effect of encapsulated and not encapsulated probiotics supplementation on In-vitro fermentation parameters $\mathrm{pH}$ value, ammonia and total volatile fatty acids (TVFA's) concentration after 24 hours incubation period are presented in Table (4). Totalvolatile fatty acids are the ultimate product of microbial fermentation in the rumen and they are the main source of metabolizable energy for ruminants (Van Soest, 1982). The not encapsulated and encapsulated probiotics bacteria and Sodium Alginate supplementation resulted significant increase in total volatile fatty acid concentration after 24 hours incubation period compared to the not supplemented experimental ration (control ration). These may be due to the higher DM and OM degradation rate (Table 2) and gas production (Table 3) recorded for the treatment supplemented with not encapsulated probiotic. The heist TVFA's concentration was recorded for not encapsulated probiotic $(7.71 \mathrm{mg} \%)$ followed by sodium alginate medium (7.69 $\mathrm{mg} \%)$ then encapsulated probiotic (7.01 $\mathrm{mg} \%$ ), while the lowest value was recorded for control $(6.04 \mathrm{mg} \%)$.

Concerning to ammonia concentration the data of Table (4) showed that the treatments supplemented with encapsulated probiotics and SA medium recorded significantly lower ammonia concentration compared to the control treatment and the treatment supplemented with not encapsulated probiotics. And no significant difference between control treatment and the treatment supplemented with not encapsulated probiotics.

Encapsulated and not encapsulated probiotics bacteria supplementation resulted in significant reduction in $\mathrm{pH}$ value after 24 hours incubation period compared to the not supplemented experimental ration (control ration). These results may be due to effect of the increase of total volatile fatty acids recorded for the treatments supplemented with not encapsulated and encapsulated probiotics bacteria and Sodium Alginate compared to the control treatments (Table 4).

Table 4, Effect of encapsulated and not encapsulated probiotics supplementation on in vitro fermentation parameters after 24 hours incubation period.

\begin{tabular}{|c|c|c|c|c|c|c|}
\hline Item & Control & Probiotic & Alginate & $\begin{array}{c}\text { Encapsulated } \\
\text { probiotic }\end{array}$ & SE & P value \\
\hline $\mathrm{pH}$ & $5.77^{\mathrm{a}}$ & $5.56^{\mathrm{d}}$ & $5.61^{\mathrm{c}}$ & $5.71^{\mathrm{b}}$ & 0.015 & 0.0001 \\
$\begin{array}{c}\text { Ammonia, } \mathrm{mg} / \mathrm{dl} \\
\begin{array}{c}\text { Total Volatile fatty acid, } \\
\text { meg/dl }\end{array}\end{array}$ & $14.42^{\mathrm{a}}$ & $13.19^{\mathrm{ab}}$ & $10.47^{\mathrm{c}}$ & $11.55^{\mathrm{bc}}$ & 0.565 & 0.0017 \\
\hline
\end{tabular}

${ }^{a},{ }^{b}$ and ${ }^{c}$ Different superscript are significantly different $(\mathrm{P}<0.05)$ 


\section{Makled, Khorshed, Gouda, El-Garhi, Ebeid, Azzaz, Abdelgawad, Mona Zayed, Hoda El-Sayed}

and El-Bordeny

\section{CONCLUSION}

It could be concluded that, adding probiotics bacteria at dose of $10^{6} \mathrm{CFU} / \mathrm{kg}$ DM feed to experimental ration resulted increase DM and OM degradability. Also using encapsulated probiotics bacteria had no significant effect on DM degradability and may be induce decrease in gas production and some fermentation parameters

\section{ACKNOWLEDGEMENTS}

All authors would like to express their thankful to The Science \& Technology Development Fund (STDF), Ministry of Higher Education \& Scientific Research, Egypt for providing financial support for this study through national challenges target project " Production of probiotics and evaluation its impact on dairy and beef cattle performance, ID10802".

\section{REFERENCES}

Allen, S. J., Wareham, K., Wang, D., Bradley, C., Hutchings, H., Harris, W. and Mack, D. 2013. Lactobacilli and bifidobacteria in the prevention of antibiotic-associated diarrhoea and Clostridium difficilediarrhoea in older inpatients (PLACIDE): a randomised, double-blind, placebo-controlled, multicentre trial. The Lancet, 382, 1249-1257.

AOAC, 1997. Association of Official Analytical Chemists. Official Methods of Analysis, vol. 16, $3^{\text {rd }}$ Revision, Gaithersburg, MD, USA.

Aottouri, N., Bouras, M., Tome, D., Marcos, A., and Lemonnier, D., 2002. Oral ingestion of lactic-acid bacteria by rats increases lymphocyte proliferation and interferon- $y$ production. British J. of Nutr., 87(4), 367-373.

Barnett, A.J.G. and Reid, R.L., 1957. Studies on the production of volatile fatty acids from the grass by rumen liquor in an artificial rumen. $\mathbf{J}$. Agric. Sci, 48, 315-321.

Blu, M., and Ørskov, E.R., 1993. Comparison of in vitro gas production and nylon bag degradability of roughages in predicting feed intake in cattle. Anim. Fed. Sci. \& Technology, 40(2-3), 109-119.

Casas, I. A., and Dobrogosz, W.J., 2000. Validation of the probiotic concep\&t: Lactobacillus reuteri confers broad-spectrum protection against disease in humans and animals. Microbial Ecology in Health and Disease, 12(4), 247-285.
Ceslovas, J., Vigilijus, J. and Almantas, S., 2005. The effect of probiotic and phytobiotics on meat properities and quality in pigs. Vet. Zootech., 29, 80-84.

Chávarri, M., Marañón, I., Ares, R., Ibáñez, F.C., Marzo, F. and del Carmen Villarán, M., 2010. Microencapsulation of a probiotic and prebiotic in alginate-chitosan capsules improves survival in simulated gastro-intestinal conditions. International Journal of Food Microbiology, 142(1-2), 185-189.

Chiquette J., Allison M.J. and Rasmussen M A, 2008. Prevotella bryantii 25 a used as a probiotic in early-lactation dairy cows: Effect on ruminal fermentation characteristics, milk production, and milk composition. J. of Dairy Sci., 91, 3536-3543.

Duncan, D.B., 1955.Multiple range and multiple $\mathrm{F}$ tests. Biometrics, 11(1), 1-42.

Edens, F. W., 2003. An alternative for antibiotic se in poultry: probiotics. Revista Brasileira de Ciência Avícola, 5(2), 75-97.

El-Shafei, K., Abdallah, N.A., Tawfik, N.F., ElSayed, H.S., and Mahmoud, M., 2018.Effect of different microencapsulating materials on survivability of Streptococcus thermophilus under simulated food processing and gastrointestinal conditions. Sciences, 8(01), 259-271.

Fuller, R., 1989. Probiotics in man and animals. J. of Applied Bact., 66, 365-378.

Ganai, A.M., Sharma, T. and Dhuria, R.K. 2015. Effect of yeast (Saccharomyces cerevisiae) supplementation on ruminal digestion of bajra (Pennisetumglaucum) straw and bajra strawbased complete feed in-vitro. Anim. Nutr. Feed Technol. 15, 145-153.

Jiang, T., Mustapha, A., and Savaiano, D.A., 1996. Improvement of lactose digestion in humans by ingestion of unfermented milk containing Bifidobacterium longum. J. of Dairy Sci., 79(5), 750-757.

McDougall, E.I., 1948. Studies on ruminant saliva. 1. The composition and output of sheep's saliva. Biochemical Journal, 43(1), 99-108.

Menke, K.H. and Steingass, H. 1988. Estimation of the energetic feed value from chemical analysis and in vitro gas production using rumen fuid. Anim. Res. and Dev., 28, 7-55.

NRC, 2001. Nutrient Requirements of Dairy Cattle. $7^{\text {th }}$ Rev. Ed. National Academy Press, Washington, DC, USA.

S.A.S., 1998. Statistical Analysis System. User's Guide Inst., Inc. Cary, NC, USA. 
In vitro evaluation of encapsulated probiotic bacteria supplementation to ruminant rations $\mathbf{3 8 1}$

Salem A.Z.M., Kholif A.E., Elghandour M.M.Y., Hernandez S.R., Domínguez-Vara I.A. and Mellado M. 2014. Effect of increasing levels of seven tree species extracts added to a high concentrate diet on in vitro rumen gas output. Anim. Sci. J., 85, 853-860.

Sheikh, G.G., Ganai, A. M., Ahmad, I., Afzal, Y., and Ali, H. 2017. In vitro effect of probiotic mix and fibrolytic enzyme mixture on digestibility of paddy straw. Advances in Animal and Veterinary Sciences, 5(6), 1-7.

Stein, D.R., Allen, D.T., Perry, E.B., Bruner, J.C., Gates, K.W., Rehberger, T.G. and Spicer, L.J. 2006. Effects of Feeding Propioni bacteria to Dairy Cows on Milk Yield, Milk Components, and Reproduction1. J. of Dairy Sci., 89(1), 111-125.

Szumacher-Strabel, M., Potkanski, A., Kowalczyk, J., Cieslak, A., Czauderna, M., Gubala, A., and Jedroszkowiak, P., 2002. Influence of supplemental fat on rumen volatile fatty acid profile, ammonia and $\mathrm{pH}$ level in sheep feed standard diet. J. of Animal and Feed Sci., 11(4), 577-588.

Tripathi M.K. and Karim S.A. 2009. Effect of individual and mixed live yeast culture feeding on growth performance, nutrient utilization and microbial crude protein synthesis inlambs. Animal Feed Sci. Technol., 155(2-4), 163-171.

VanSoest P.J., 1982. Nutritional ecology of the ruminant. Cornell University Press, Ithaca, NY, USA.

VanSoest, P.V., Robertson, J.B. and Lewis, B.A. 1991. Methods for dietary fiber, neutral detergent fiber, and nonstarch polysaccharides in relation to animal nutrition. J. of Dairy Sci., 74(10), 3583-3597.

Weiss, W.P., Wyatt, D.J., and McKelvey, T.R. 2008. Effect of feeding propionibacteria on milk production by early lactation dairy cows. J. of Dairy Sci., 91(2), 646-652.

Yoon, I.K. and Stern, M.D., 1995. Influence of direct-fed microbials on ruminal microbial fermentation and performance of ruminants: A review. Asian-Aust. J. Anim. Sci., 8(6),533-555. 



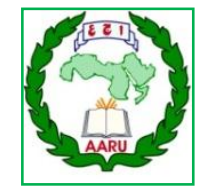

المؤتمر الرابع عشر لبحوث التنمية الزراعية،

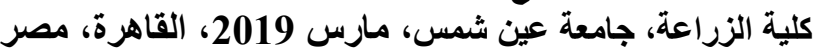

مجلد(27)، عدد (1)، عداد خاص مارس،

Website: http://strategy-plan.asu.edu.eg/AUJASCl/

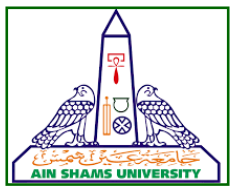

دراسه معمليه لتأثير اضافه البروييوتيك المغلفه لعلائق المجترات

[35]

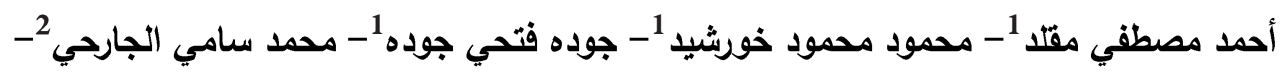

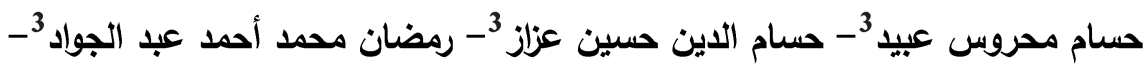

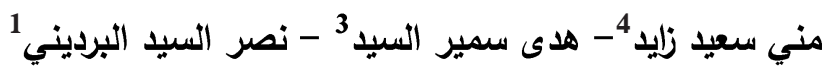

1.قسم الانتاج الحيوانى - كلية الزراعة - جامعة عين شمس - ص. ب. بـ 68 حدائق شبرا

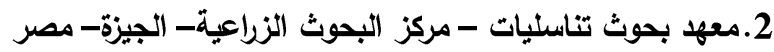

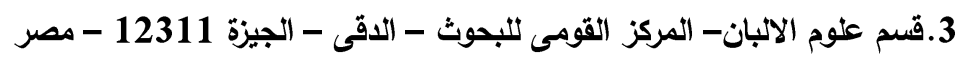

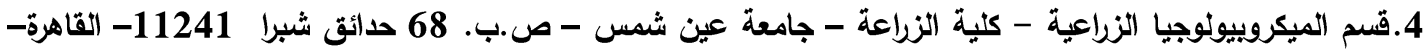

مصر

*Corresponding author: ahmed.makled59@gamil.com

Received 8 December, 2018,

Accepted 8 January, 2019

لم تلاحظ اختلافات معنويه بين العليقه الضابطة

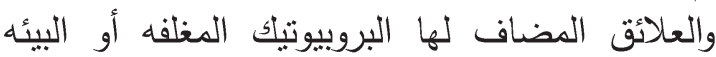

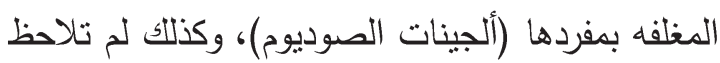

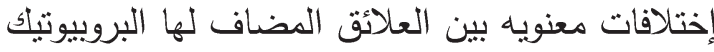
المغلفه والعلائق المضاف لها لين البيئات المغلفه بمفردها.

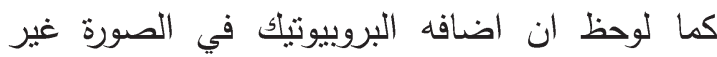

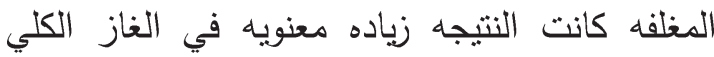

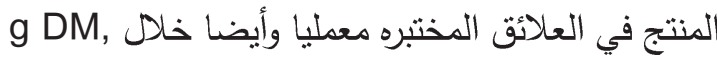
OM, dDM, NDF, ADF التحضين مقارنه بالعلائق المختبره (الضابطة والبروبيوتيكا المغلفه والبيئات المغلفه فقط). بينما حدثت

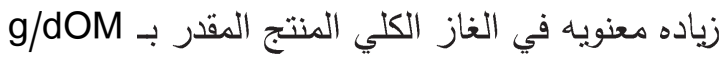
في البروبيوتيك المغلفه. ويمكن من خلال هذه النئ النتائج استتناج أن استخدام البروبيوتئك المغلف ليس لهان لهان تأثنير

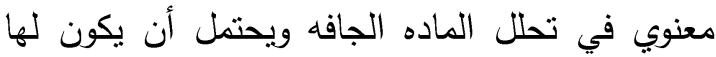
دور في تقليل حجم الغاز المنتج ومقايس التخمر . لإن

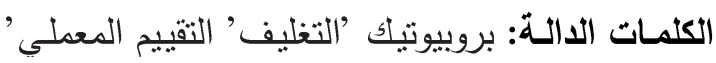

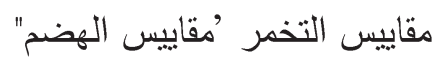

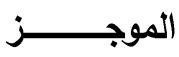

الهدف من هذه الدراسه هو تقييم مستوايات مختلفه لاضافه البروبيوتيك في علائق الحيوانات المجتره بإستخدام التخمرات المعمليه وتقدير مستويات التئير التخمر

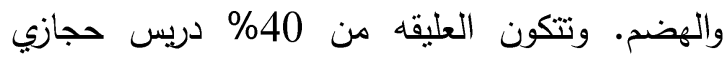
و60\% خليط مواد مركزه. تم اضافه البروبيوتك المغلفه وغير المغلفه بتركيز $10^{6}$ cfu/kg علي أساس الماده

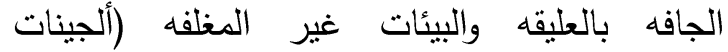
الصوديوم) تم استخدامها للمقارنه بالمجموعه الضابطة.

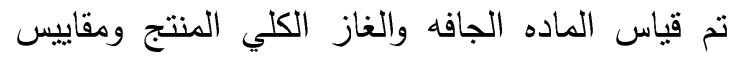

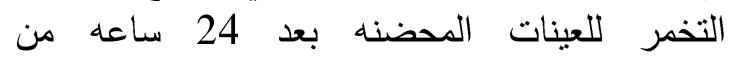

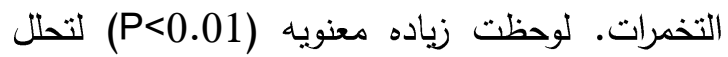
الماده الجافه في العلائق المضاف لهان البروبيه المغلفه وغير المغلفه بتركيز (CFU/ kg DM 106) وعلائق ألجينات الصوديوم (البيئه المغلفه) مقارنه

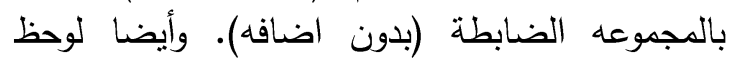
وجود فرق معنوي (P>0.05) كتحسن في تحلل الماده

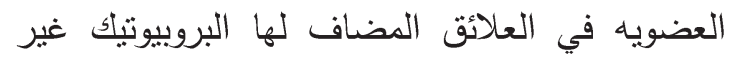
المغلفه مقارنه بباقي المعاملات. وعلاوه علي ذلت التك 